\title{
Impact of Product Packaging on Consumer Buying Decision
}

\author{
Suman Prosad Saha \\ Independent University, Bangladesh
}

\begin{abstract}
Packaging is an integral part of any product that attracts consumer. Many firms have used packaging as a promotional tool in their marketing campaigns. Hence, this research aims to explore the key factors of packaging that influence consumers in Fast Moving Consumer Goods industry of Bangladesh. Data was collected via structured questionnaire from 338 respondents and analyzed using Statistical Package for the Social Sciences to evaluate the strength of hypothesized relationship, if any, among the constructs, which include Color of Packaging, Materials of Packaging, Attractiveness of Wrapping Design, Labeling, and Innovative Packaging as independent variables or predictors and Consumer Buying Decision as the dependent variable. The results provide enough evidence to support the hypothesized relationship and useful information for managers in formulating strategies to influence consumers regarding buying decision behavior.
\end{abstract}

\section{Key words: Product Packaging, Consumer Buying Decision, Bangladesh}

\section{INTRODUCTION}

Consumers are vastly fond of new products and services which will satisfy their needs and fulfill their demands. We can easily identify the consumer's buying behavior towards any product or service by understanding their attraction towards the product, how will they react towards the product, what is the perception of the consumers about the product or service offered by a company. Product packaging is treated by most marketers as a component of product strategy. Almost every marketing communications strategy involves packaging because of its heavy influence on consumer decision making behavior. Firms are interested in packaging as a tool to increase their sales as well as to reduce promotional costs (Zekiri and Hasani, 2015).

Packaging attracts consumers and increases its sale. It also reduces the marketing and advertisement cost of the product. In the past decades companies are not focused on their product packaging. Manufacturers should design packaging in a way that promote product sales. According to Deliya\&Parmar (2012), packaging will influence consumers and consequently change their buying behavior towards that particular brand which will help the firm to generate revenue. Consumers did not attract towards the product and didn't purchase which will cause lack sale. But now companies are more focusing on the product packaging as there is a tough competition among all the Fast-moving Consumer goods (FMCG) products. Previous researches show that there is a disagreement between packaging quality and consumers buying behavior.

The objective of this study is to investigate peoples' perception about the role of packaging on consumer buying decisions. Identifying the key elements of packaging is also the purpose of this research. A theoretical model was developed by conducting a literature review. A structured questionnaire was developed for data collection and respondents from several distribution firms were selected. Analysis and finding are provided in the results section including some statistical analyses. Last part of this paper provides some suggestions for the marketers on how to improve the quality of product's packaging.

\section{Literature Review \\ Color of Packaging}

Manufacturers have been using color in their products' packaging to influence consumers while making their buying decisions because it is usually evocative and memorable. Gofman et al., (2010) says that color plays a significant role for product selection. Consumers expect certain types of color for particular product which makes color a fundamental part of packaging (Keller, 2009). It is crucial for manufacturers to keep in mind that different colors symbolize different meaning while choosing packaging colors. For example, 
black is to evoke mystery and power, blue is to convey trust, white is to portray purity and simplicity, and red draws attention. Most of the religions are believed to have their own sacred colors and meaning of color varies between cultures (Singh, 2006).

\section{Materials of Packaging}

The main purpose of a package is to hold or contain the product. For this reason, it is pivotal to use good quality materials which prevent the product from any danger or loss. A well-known notion is that higher quality materials usually attract consumers more compare to lower quality materials. According to Baik (2011), upper class people are heavily influenced by superior elements that are used in packaging. Certain materials could change a consumer's perception about the quality of a product (Smith and Taylor, 2004). Most of respondents in a study on milk packaging carried out by Hollywood et al., (2013) agreed that the use of plastic containers were better than cardboard and glass packaging.

\section{Attractiveness of Wrapping Design}

According to Orth and Crouch (2014), packaging can be used for identifying a product as well as attracting a consumer. A well planned and eye-catching design can easily attract a consumer. It also helps manufacturers to differentiate their products on the shelves of retailers.

\section{Labeling}

Labeling helps consumers to acquire information regarding the product category, product ingredients, and product instructions. Marketers can use information on packaging to establish brand image and support their marketing communication strategies. Labeling is a key component of the marketing mix and the most visible part of a product (Shah et al., 2013). According to Morris, J (1997) consumers can easily differentiate a product based on labling. Moreover, these days consumers show deep interest to label information since they are more concerned with health and nutrition issues (Coulson, N.S., 2000).

\section{Innovative Packaging}

Bringing innovation in the packaging design also increase the value of the product in the consumer mind. Novel packaging can attract consumers, but practicality is equally important. Innovative packaging may actually add value to the product if it meets a consumer needs. But, its practicality also very important to create the added value, like easily opening, easily stored, environmental friendly packaging, recyclable, etc. A study conducted by Borin et al. (2011), performed an investigation that showed an evaluation of environmentally benign products versus products which have negative environmental impacts. Nowadays, manufacturers try to design packaging that maintains the key equities of the brand in order to appeal to customers' needs and preferences. Changes in consumption patterns and habits are requiring innovative packaging solutions in retail outlets (Rundh, 2005).

The hypotheses are formulated based on the literature review to build a conceptual model for the research. The proposed study considers the following hypotheses:

H1: Color of Packaging is positively related to Consumer Buying Decision

$\mathrm{H} 2$ : Materials of Packaging is positively related to Consumer Buying Decision

H3: Attractiveness of Wrapping Design is positively related to Consumer Buying Decision

H4: Labelling is positively related to Consumer Buying Decision

H5: Innovative Packaging is positively related to Consumer Buying Decision

\section{Data \& Methodology Research design}

In this research, there are five independent variables and one dependent variable. So a change in the independent variables will change the dependent variable. Therefore, to investigate the research questions and test the hypothesis a Causal study is required. This study focuses on analyzing the relationship between product packaging and consumer buying decision. This study also explains the structure of a relationship between independent and dependent variables. For this reason, this study can be considered as Causal or Explanatory research. Explanatory research indicates a relationship between variables as well as the direction of the relationship.

\section{Sampling Method}

For this research, random sampling method was used. According to Teddlie and Yu (2007), Random sampling occurs when each sampling unit in a clearly defined population has an equal chance of being included in the sample. In this study, Dhaka city (Capitol city) was selected as population and consumers were selected on a Random sampling method. Respondents from several areas were approached in different parts of Dhaka city with the questionnaire and information was collected on the spot.

\section{Questionnaire Design and Data collection}

This reaserch follows a pattern of structured questionnaire and for a better understading of the respondents it was divided into two parts. Demographic factor of the respondents were included in the first part. Considering the comfort of respondents these questions were constructed with multiple choices. Questions for both the independent and dependent variables were incorporated in the second part of the questionanire. Each item was rated on a Likert Scale (1 to 5) which 
ranges on a continuum from strongly agree to strongly disagree.

The distribution of questionanires over a large population is a must for generating realistic outcome. Thus, the survey questionnaires were designed to apply to a heterogeneous population, where targeted respondents come from the general open public (from different genders, races, age groups, marital status, education backgrounds, and designations).

The questionnaires were distributed among the 338 respondents. The questionnaires were surveyed physically and via technological platform such as email. The questionnaires was prepared in both Bengali (Native Language) and English for the convenience of the respondents. The aim was to collect the opinions of the respondents in respond to several factors affecting consumer buying decision behavior while purchasing any FMCG product. The data collection procedure took place from the month of September to November 2018. All collected data was fed into the Statistical Package for the Social Sciences (SPSS) for analysis. All information and the identity of the respondent were strictly confidential and will not to be disclosed to any party in any manner.

Table 1: Reliability analysis

\begin{tabular}{|l|c|c|}
\hline \multicolumn{1}{|c|}{ Dimensions } & Number of Items & Cronbach's $\alpha$ \\
\hline Color of packaging & 3 & 0.732 \\
\hline Materials of packaging & 3 & 0.759 \\
\hline $\begin{array}{l}\text { Attractiveness of wrapping } \\
\text { design }\end{array}$ & 3 & 0.783 \\
\hline Labeling & 3 & 0.737 \\
\hline Innovative packaging & 4 & 0.782 \\
\hline Consumer buying decision & 3 & 0.837 \\
\hline
\end{tabular}

\section{Pearson Correlation}

A correlation coefficient is a very useful way to summarize the relationship between two variables with a single number that falls between -1 and +1 (Welkowitz et al., 2006). Cohen and Lea (2004) stated that: -1.0 (a perfect negative correlation), 0 (no correlation), and +1.0 (a perfect positive correlation).

H1a: Color of Packaging is positively related to Consumer Buying Decision

$\mathrm{H} 1 \mathrm{a} 0$ : Color of Packaging is not positively related to Consumer Buying Decision

Table 2 shows that the correlation (r) of Color of Packaging is 0.868 and the significant level is 0.000 (p $\leq 0.05$. The table shows that the $\mathrm{p}$-value is 0.000 , which is less than 0.01 . Therefore, the null hypothesis is rejected, and concluded that there is a significant positive $(r=0.868)$ relationship between Color of Packaging and Consumer Buying Decision in FMCG industry in Bangladesh.

\section{Results}

A total of 338 respondents were used in the analysis and $71 \%$ (240 participants) comprised of male respondents and 29\% (98 participants) comprised of female respondents. Of the respondents who participated in the survey, $155(45.85 \%)$ respondents were in the age range of 18 to 25 years; 110 respondents $(32.54 \%)$ were in the age range of 26 to 40 years; 45 respondents (13.41) were in the age range of 41 to 60 years; and $28(8.28 \%)$ male respondents were above 60 years.

All accumulated data were analyzed using statistical software SPSS, version 21. Reliability findings (Cronbach's Alpha) of the multiple items were performed to measure the internal consistency. According to George (2003), reliability coefficient of 0.7 is acceptable, more than 0.8 is good and more than 0.9 is considered excellent. Table 1 shows that all constructs met the reliability test. Five of the variables have Alpha value in "acceptable" range and one in "good" range.
H2a: Materials of Packaging is positively related to Consumer Buying Decision

$\mathrm{H} 2 \mathrm{a} 0$ : Materials of Packaging is not positively related to Consumer Buying Decision

From Table 2, it can be observed that the correlation (r) of Materials of Packaging is 0.812 and the significant level is $.000(\mathrm{p} \leq 0.05)$. The table shows that the $\mathrm{p}$-value is 0.000 , which is less than 0.01 . Therefore, the null hypothesis is rejected, and concluded that there is a significant positive $(\mathrm{r}=0.812)$ relationship between Materials of Packaging and Consumer Buying Decision.

H3a: Attractiveness of Wrapping Design is positively related to Consumer Buying Decision

H3a0: Attractiveness of Wrapping Design is not positively related to Consumer Buying Decision

From Table 2, it is discernible that the correlation (r) Attractive wrapping design is 0.826 and the significant level is $.000(\mathrm{p} \leq 0.05)$. The table displays that the $\mathrm{p}$ value is 0.000 , which is less than 0.01 . Therefore, the 
null hypothesis is rejected, and concluded that there is a significant positive $(\mathrm{r}=0.826)$ relationship between I Attractive wrapping design and Consumer Buying Decision in FMCG industry in Bangladesh.

H4a: Labeling is positively related to Consumer Buying Decision

$\mathrm{H} 4 \mathrm{a} 0$ : Labeling is not positively related to Consumer Buying Decision

Table 2 shows that the correlation ( $r$ ) of Labeling is 0.871 and the significant level is 0.000 ( $p \leq 0.05$. The table indicates that the p-value is 0.000 , which is less than 0.01 . Therefore, the null hypothesis is rejected, and deduced that there is a significant positive $(r=0.871)$ relationship between Labeling of Packaging and Consumer Buying Decision.

Table 2: Pearson Correlation matrix

\begin{tabular}{|c|c|c|c|c|c|c|c|}
\hline & $\begin{array}{l}\text { Consumer } \\
\text { Buying } \\
\text { Decision }\end{array}$ & $\begin{array}{l}\text { Color of } \\
\text { Packaging }\end{array}$ & $\begin{array}{l}\text { Materials of } \\
\text { Packaging }\end{array}$ & $\begin{array}{l}\text { Attractive } \\
\text { wrapping }\end{array}$ & Labeling & $\begin{array}{l}\text { Innovative } \\
\text { Packaging }\end{array}$ & $\begin{array}{l}\text { Sig. } \\
\text { tailed })\end{array}$ \\
\hline $\begin{array}{l}\text { Consumer } \\
\text { Buying Decision }\end{array}$ & 1 & $0.868 * *$ & $0.812 * *$ & $0.826^{* *}$ & $0.871 * *$ & $0.891 * *$ & 0.000 \\
\hline $\begin{array}{ll}\text { Color } & \text { of } \\
\text { Packaging } & \end{array}$ & $0.868 * *$ & 1 & $0.805^{* *}$ & $0.798 * *$ & $0.813 * *$ & $0.768 * *$ & 0.000 \\
\hline $\begin{array}{l}\text { Materials of } \\
\text { Packaging }\end{array}$ & $0.812^{* *}$ & $0.805 * *$ & 1 & $0.837 * *$ & $0.821 * *$ & $0.879 * *$ & 0.000 \\
\hline $\begin{array}{l}\text { Attractive } \\
\text { wrapping }\end{array}$ & $0.826 * *$ & $0.798 * *$ & $0.837^{* *}$ & 1 & $0.797 * *$ & $0.785^{* *}$ & 0.000 \\
\hline Labeling & $0.871 * *$ & $0.813 * *$ & $0.821 * *$ & $0.797 * *$ & 1 & $0.816^{* *}$ & 0.000 \\
\hline $\begin{array}{l}\text { Innovative } \\
\text { Packaging }\end{array}$ & $0.891 * *$ & $0.768 * *$ & $0.879 * *$ & $0.785^{* *}$ & $0.816^{* *}$ & 1 & 0.000 \\
\hline & & **. Correl & is signific & at the 0.0 & vel (2-tai & & \\
\hline
\end{tabular}

In statistics, the correlation coefficient $r$ measures the strength and direction of a linear relationship between two variables on a scatterplot. The value of $r$ is always between +1 and -1 . According to Taylor (1990), correlation $r$ is closest to:

Exactly -1. A perfect downhill (negative) linear relationship

-0.70 . A strong downhill (negative) linear relationship -0.50 . A moderate downhill (negative) relationship -0.30 . A weak downhill (negative) linear relationship

0 . No linear relationship

+0.30 . A weak uphill (positive) linear relationship +0.50 . A moderate uphill (positive) relationship +0.70 . A strong uphill (positive) linear relationship Exactly +1. A perfect uphill (positive) linear relationship

In this study, it is found that, for all five correlations, the $r$ value is greater than +0.70 which indicates the existence of a strong uphill (positive) relationship.
H5a: Innovative Packaging is positively related to Consumer Buying Decision

H5a0: Innovative Packaging is not positively related to Consumer Buying Decision

According to Table 2, the strongest predictor of Consumer Buying Decision is Innovative Packaging. The result indicates that the correlation ( $r$ ) of the attractive wrapping design is 0.891 and the significant level is $0.000(\mathrm{p} \leq 0.05)$. The table shows that the $\mathrm{p}$-value is 0.000 , which is less than 0.01. Therefore, the null hypothesis is rejected, and concluded that there is a significant positive $(\mathrm{r}=0.891)$ relationship between Innovative Packaging and Consumer Buying Decision. 
independent errors (autocorrelation). The value of this statistic between 2 or close to 2 is considered as better and Table 3 indicates the value is 1.639 , which is very close to 2 (Gujarati and Porter, 1999). Therefore, the assumption has almost been accomplished. Finally, it can be said that the model for this research is valid and reliable.

$\mathrm{Y}=\alpha+\beta 1$ (Color) $+\beta 2$ (Materials) $+\beta 3$ (Wrapping) + $\beta 4$ (Labeling) $+\beta 5$ (Innovativeness)

$\mathrm{Y}=-0.165+0.275+0.167+0.236+0.289+0.314$

Here $\mathrm{Y}$ is the Consumer Buying Decision and $\alpha$, the constant. The results in Table 3 show that the

Table 3: Multiple Regression analysis results

\begin{tabular}{|c|c|c|c|c|c|c|}
\hline \multirow[b]{3}{*}{ Color } & \multicolumn{2}{|c|}{$\begin{array}{l}\text { Unstandardized } \\
\text { Coefficients }\end{array}$} & \multirow[t]{2}{*}{$\begin{array}{c}\text { Standardized } \\
\text { Coefficients }(\beta)\end{array}$} & \multirow[t]{2}{*}{ t-Value } & \multirow[t]{2}{*}{ Significance } & \multirow[t]{2}{*}{ VIF } \\
\hline & & & & & & \\
\hline & 0.214 & 0.051 & 0.275 & 4.173 & $0.000^{* *}$ & 1.135 \\
\hline Materials & 0.276 & 0.046 & 0.167 & 6.046 & $0.000 * *$ & 2.140 \\
\hline Wrapping Design & 0.316 & 0.045 & 0.236 & 7.026 & $0.000 * *$ & 1.953 \\
\hline Labeling & 0.283 & 0.053 & 0.289 & & $0.000 * *$ & 1.643 \\
\hline Innovativeness & 0.261 & 0.042 & 0.314 & & $0.000 * *$ & 2.138 \\
\hline \multicolumn{7}{|l|}{ Other Values } \\
\hline $\begin{array}{l}\text { Intercept } \\
\text { (Constant) }\end{array}$ & \multicolumn{6}{|c|}{-0.165} \\
\hline $\mathrm{R}^{2}$ & \multicolumn{6}{|c|}{0.518} \\
\hline Adjusted $\mathrm{R}^{2}$ & \multicolumn{6}{|c|}{0.496} \\
\hline Durbin-Watson & \multicolumn{6}{|c|}{1.639} \\
\hline
\end{tabular}

Analysis of variance (ANNOVA) assesses the overall significance of the model (Hoaglin \& Welsch, 1978). Table 4 shows that the model is significant as $P$ value is $<0.05$. Table 4 also shows that all the independent variables have a positive impact on

Table 4: Analysis of Variance (ANNOVA) results

\begin{tabular}{|l|c|c|c|c|c|}
\hline Sources of Variation & Sum of Squares & df & Mean Square & F & Sig. \\
\hline Regression & 23.260 & 3 & 7.753 & 12.905 & $0.000^{* *}$ \\
\hline Residual & 21.629 & 36 & 0.601 & & \\
\hline Total & 44.889 & 39 & & & \\
\hline
\end{tabular}

\section{Concluding Comments}

This research shows that packaging has substantial influence on a consumer's decision making process. In this study it is found that the highest relationship existed between the innovativeness of packaging and consumer buying behavior. The lowest relationship is, between materials of packaging and consumer buying decision. There is a significant relationship among all attributes of packaging. Results show that packaging has reasonable impact on customers as per their attitude and buying intention. It has also been highlighted that packaging can combination of all the independent variables together contributed to $51.8 \%$ effect on Consumer Buying Decision. The $\mathrm{R}^{2}$ for the overall study on the three predictors suggests that there is a powerful effect of all five independent variables on Consumer Buying Decision. From the table, it can be concluded that all the five Independent variables have a significant effect on Dependent variable $(p-$ value $=0.000)$. By analyzing the Beta values, it can be observed that Innovativeness of Packaging is most influential for Consumer Buying Decision with $31.4 \%$ whereas Color, Materials, Wrapping Design and Labeling stands $27.5 \%, 16.7 \%$, $23.6 \%$, and $28.9 \%$ respectively.
Consumer Buying Decision. The coefficients of these variables are positive and significant at 5 percent level of significance, hence rejecting the null hypotheses.

boost up the sales and purchase of product, people like to buy the products more if the product contains a robust and attractive packaging. The result of this study has proven the research model framework is a very effective model to measure the effect of packaging on consumer buying desicion in the FMCG industry of Bangladesh. Marketers should use all the elements of packaging in their marketing communications strategy to influence consumers as consumers perceive these elements as decision making factors regarding their purchase. Color on package makes a product attractive and noticeable 
and it can be used creatively to help consumers differentiate their favorite brands. Good quality materials also build trust in consumers' mind about the brand. Labeling helps manufacturers to describe and promote their products. Labeling also aids a consumer in identifying a product and facilitates decision making process. Innovative packaging compels a consumer to look at any product in an inquisitive way.

It is indispensable to mention some limitations of this study. First, sample size for this research is modest. It would be desirable to replicate the findings with a larger sample although appropriate procedures has been taken to analyse and acquired results are robust in nature. Secondly, further research could also augment analysis of different industry or all the industries together as this study considered single industry only. Finally, additional insight could be gained by further expanding the unit of analysis in relationship research. For example, the analysis could be broadened to include the relationship between green and limited edition packaging and consumer buying decision which in turn may reveal different types of predictors for consumer buying decisions.

\section{Acknowledgement}

The author acknowledges the contribution of all the respondents for their valuable time in filling out the questionnaires. The author also acknowledges Centre for Business and Policy Research (CBPR) at Independent University, Bangladesh for funding this research project.

\section{References}

[1] Baik, S., (2011). "Package design management in SMEs”, .Diversity and Management, pp: 1-6.

[2] Borin, N., Cerf, D.C., \& Krishnan, R. (2011). Consumer effects of environmental impact in product labeling. Journal of Consumer Marketing, 28(1), pp. 76-86.

[3] Cohen, Barry H., and R. Brooke Lea. Essentials of statistics for the social and behavioral sciences. Vol. 3. John Wiley \& Sons, (2004): 71-76.

[4] Coulson, N.S., 2000. An application of the stages of change model to consumer use of food labels. British Food Journal, 102(9), pp.661-668.

[5] Deliya, M.M.M. and Parmar, M.B.J., 2012. Role of Packaging on Consumer Buying Behavior â€"Patan District. global Journal of management and Business research, 12(10), pp.122-137.

[6] George, Darren. SPSS for windows step by step: A simple study guide and reference, 17.0 update, 10/e. Pearson Education India, (2003): 53-55.

[7] Gofman, A., Moskowitz, H.R. and Mets, T., 2010. Accelerating structured consumer-driven package design. Journal of Consumer Marketing, 27(2), pp.157-168.

[8] Gujarati, Damodar N., and Dawn C. Porter. "Essentials of econometrics." (1999), p. 102-131.

[9] Haitovsky, Y., 1969. Multicollinearity in regression analysis: Comment. The Review of economics and statistics, p.486-489.

[10]Hollywood, L., Wells, L., Armstrong, G. and Farley, H., 2013. Thinking outside the carton: attitudes towards milk packaging. British Food Journal, 115(6), pp.899-912.

[11] Keller, K.L., 2010. Brand equity management in a multichannel, multimedia retail environment. Journal of Interactive Marketing, 24(2), pp.58-70.

[12] Morris, J., 1997. Green goods?: consumers, product labels and the environment. IEA Environment Unit.

[13] Orth, U.R. and Crouch, R.C., 2014. Is beauty in the aisles of the retailer? Package processing in visually complex contexts. Journal of Retailing, 90(4), pp.524-537.

[14] Rundh, B. (2005). The Multi-faceted dimension of packaging: marketing logistic or marketing tool? British Food Journal, 107(9), 670-84.

[15] Shah, S., Ahmad, A. and Ahmad, N., 2013. Role of packaging in consumer buying behaviour. International Review of Basic and Applied Sciences, 1(2), pp.35-41.

[16] Singh, S., 2006. Impact of color on marketing. Management decision, 44(6), pp.783-789.

[17] Silayoi, P., \& Speece, M. (2004). Packaging and purchase decisions: An exploratory study on the impact of involvement level and time pressure. British Food Journal, 106 (8), 607-628.

[18] Smith, P.R. and Taylor, J., 2004. Marketing communications: an integrated approach. Kogan Page Publishers.

[19] Taylor, Richard. "Interpretation of the correlation coefficient: a basic review."Journal of diagnostic medical sonography 6.1 (1990): 35-39.

[20] Teddlie, Charles, and Fen Yu. "Mixed methods sampling a typology with examples." Journal of mixed methods research 1.1 (2007): 77-100.

[21] Welkowitz, Joan, Barry H. Cohen, and Robert B. Ewen. Introductory statistics for the behavioural sciences. John Wiley \& Sons, (2006): 219-236.

[22]Zekiri, J. and Hasani, V.V., 2015. The role and impact of the packaging effect on consumer buying behaviour. Ecoforum Journal, 4. 